\title{
Rosaceae-feeding Nepticulidae (Lepidoptera) of South America: some taxonomic and trophic diversity revealed
}

Jonas R. Stonis ${ }^{*}$,

Arūnas Diškus ${ }^{1}$,

Andrius Remeikis ${ }^{2}$,

Nixon Cumbicus Torres ${ }^{3}$

${ }^{1}$ Lithuanian University of Educational Sciences and Baltic-American

Biotaxonomy Institute, Studentu St. 39, Vilnius LT-08106, Lithuania

${ }^{2}$ Institute of Ecology,

Nature Research Centre,

Akademijos St. 2,

Vilnius LT-08412, Lithuania

${ }^{3}$ Universidad Técnica Particular de Loja, San Cayetano Alto s/n, Loja, Ecuador
The paper reviews the most recent findings of the Rosaceaefeeding Nepticulidae species along with previous records of these tropically specialized leaf-miners in South America and describes three new species: one species on Hesperomeles obtusifolia (Pers.) Lindl (Stigmella circinata Diškus \& Stonis, sp. nov.) and two species on Rubus spp. (S. rubiphagiella Diškus \& Stonis, sp. nov. and Ectoedemia morae Diškus \& Stonis, sp. nov.); all from the equatorial Andes. Additionally, leaf-mines of the unknown Stigmella taxa feeding on Acaena L., Alchemilla L., Rubus L., Prunus L., and Hesperomeles Lindl are documented. Description of previously unknown females of Stigmella nubimontana Puplesis \& Diškus and photographic documentation of leaf-mines of S. nubimontana and S. rubeta Puplesis \& Diškus are provided for the first time. The discovered Rosaceae-feeding Nepticulidae exhibit morphological and taxonomical diversity: two new species groups, Stigmella imperatoria and S. circinata, are designated; the latter is also compared with the most similar and probably closely related Holarctic $S$. hemargyrella and S. sorbi groups.

Keywords: Ectoedemia Busck, leaf-mines, Nepticulidae, new species, Rosaceae, South America, Stigmella Schrank

\section{INTRODUCTION}

The family Nepticulidae was characterized in monographic reviews by Scoble (1983), Johansson et al. (1990), Puplesis (1994), and Puplesis, Diškus (2003), with special reference to South America also by Puplesis, Robinson (2000) and Stonis et al. (2016).

Rosaceae is a medium-sized family of flowering plants including nearly 3000 described species in more than 90 genera found almost every-

*Corresponding author. E-mail: stonis@leu.lt where except Antarctica; it primarily occurs in the Northern Hemisphere, often in non-desert or tropical forest habitats (Stevens, 2012). Rosaceae is the predominant host-plant family in the Palearctics (Puplesis, 1994). As regards the Neotropical Nepticulidae, it is unfortunate that in the early stage of research, the majority of species were described without providing host-plant data (i. e., species descriptions were based on non-reared material). Only a small portion of the species was known as leaf-miners of plants from a few families such as Fabaceae, Malvaceae, Polygonaceae (see Puplesis \& Robinson 2000), etc., but almost 
none from Rosaceae. There is an exception: a paper describing two Rubus-feeding species from central Ecuador by Puplesis et al. (2002). (Note: the history of investigating Nepticulidae in the Neotropics and the Ando-Patagonian region was provided by Stonis et al., 2016).

The Rosaceae-feeding Nepticulidae became better known thanks to recent field research in South America (particularly in Peru and Ecuador). A recent publication by Stonis et al. (2016) provided descriptions of three new Polylepisfeeding species from Peru and Ecuador along with documentation of leaf-mines on Polylepis of an unknown taxon from Peru. In this paper, we review our recent findings together with all previous records of the Rosaceae-feeding Nepticulidae species in South America. We describe two new Stigmella species trophically associated with Rubus L. and Hesperomeles Lindl. and one Ectoedemia species trophically associated with Rubus L. as well as document leaf-mines on Acaena L., Alchemilla L., Rubus L., Prunus L., and Hesperomeles Lindl., which belong to an unknown Rosaceae-feeding taxa.

\section{MATERIALS AND METHODS}

Descriptions of new species are based on material deposited in the collection of the Zoological Museum, Natural History Museum of Denmark in Copenhagen, Denmark, which was collected in Ecuador (by A. Diškus and J. R. Stonis, formerly by R. Puplesis, thanks to various research projects together with Ecuadorian scientific partners, including the initial project of 1999 by R. Puplesis and S. R. Hill together with our esteemed Professor Giovanni Onore, former professor at the Pontifical Catholic University of Ecuador, Quito, Ecuador).

Collecting methods and protocols for species identification and description are outlined in Puplesis (1994); Puplesis, Robinson (2000); and Puplesis, Diškus (2003). After maceration of the abdomen in $10 \% \mathrm{KOH}$ and subsequent cleaning, male genital capsules were removed from the abdomen and mounted ventral side uppermost. The phallus was removed and mounted in Euparal separately but on the same genitalia slide. Abdominal pelts and female genitalia were stained with Chlorazol Black (Direct Black 38/Azo Black) (for a detailed description of the method see Stonis et al., 2014).

Permanent slides were photographed and studied using a Leica DM2500 microscope and Leica DFC420 digital camera. The descriptive terminology of morphological structures follows Puplesis, Robinson (2000), except for the term "aedeagus", which is referred here as "phallus", and the term "cilia", which is referred here as "fringe".

Institutional abbreviations used in the text: BMNH - The Natural History Museum, London, United Kingdom; ZMUC - Zoological Museum, University of Copenhagen, Denmark.

\section{RESULTS}

\section{Review of the Rubus-feeding Nepticulidae with description of new species} Stigmella circinata Diškus \& Stonis, sp. nov.

Type material. Holotype: $\hat{\sigma}$, ECUADOR: Pichincha Province, $11 \mathrm{~km}$ NW Alóag, $0^{\circ} 26^{\prime}$ 47"S, 78 37'33"W, elevation $3105 \mathrm{~m}$, mining larvae on Hesperomeles obtusifolia (Pers.) Lindl (Rosaceae), 9.i.2005, field card no. 4802, A. Diškus \& J. R. Stonis, genitalia slide no. AD785 $\hat{\jmath}$ (ZMUC). Paratypes: $1 \hat{\jmath}, 1$, , same label data as holotype, genitalia slides nos. AD794 ${ }^{\lambda}, A D 786$ ( all from adults in pupal skin) (ZMUC). Leaf-mines are also documented from Pichincha Province, $45 \mathrm{~km}$ E Quito, $0^{\circ} 16^{\prime} 07^{\prime \prime S}, 78^{\circ} 16^{\prime} 25^{\prime \prime} \mathrm{W}$, elevation $3290 \mathrm{~m}$.

Diagnosis. The combination of a rounded capsule, specific rounded juxta, very short vinculum, long sublateral processes of transtilla, unique set of cornuti (see Fig. 11), and the leaf-mine abruptly developing to a large blotch distinguishes $S$. circinata sp. nov. from all other Stigmella species; the host-plant Hesperomeles obtusifolia (Rosaceae) also makes this species distinctive.

Male (See Remarks).

Female (See Remarks).

Male genitalia (Figs. 8-11). Capsule little longer $(205-210 \mu \mathrm{m})$ than wide $(240 \mu \mathrm{m})$. Uncus with two pointed lobes. Gnathos with two caudal processes and very slender central plate. 

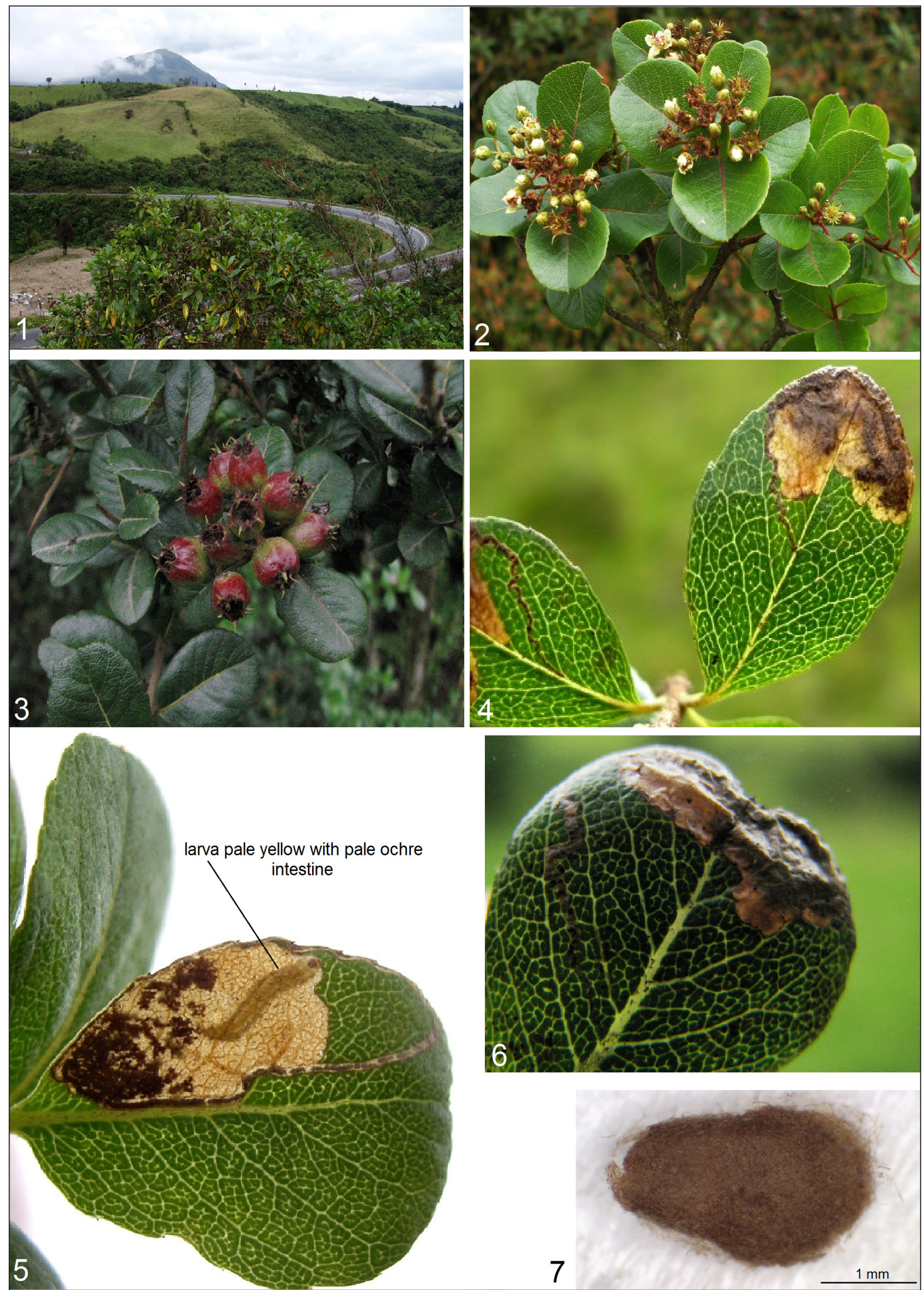

Figs. 1-7. Bionomics of Stigmella circinata Diškus \& Stonis, sp. nov. 1 - habitat; 2, 3 - host-plant Hesperomeles obtusifolia (Pers.) Lindl; 4-6 - leaf-mines; 7 - cocoon 
Valva $210-215 \mu \mathrm{m}$ long, $75-80 \mu \mathrm{m}$ wide, with one apical process; inner lobe slightly bulged; transtilla with long sublateral processes. Juxta mostly membranous, laterally and distally rounded and little thickened (Fig. 9). Vincu- lum very short, without lateral lobes. Phallus (Fig. 11) 390-395 $\mu \mathrm{m}$ long, 80-100 $\mu \mathrm{m}$ wide; vesica with a wide band of cornuti comprised of large or very large spine-like cornuti and minute lamellar ones.

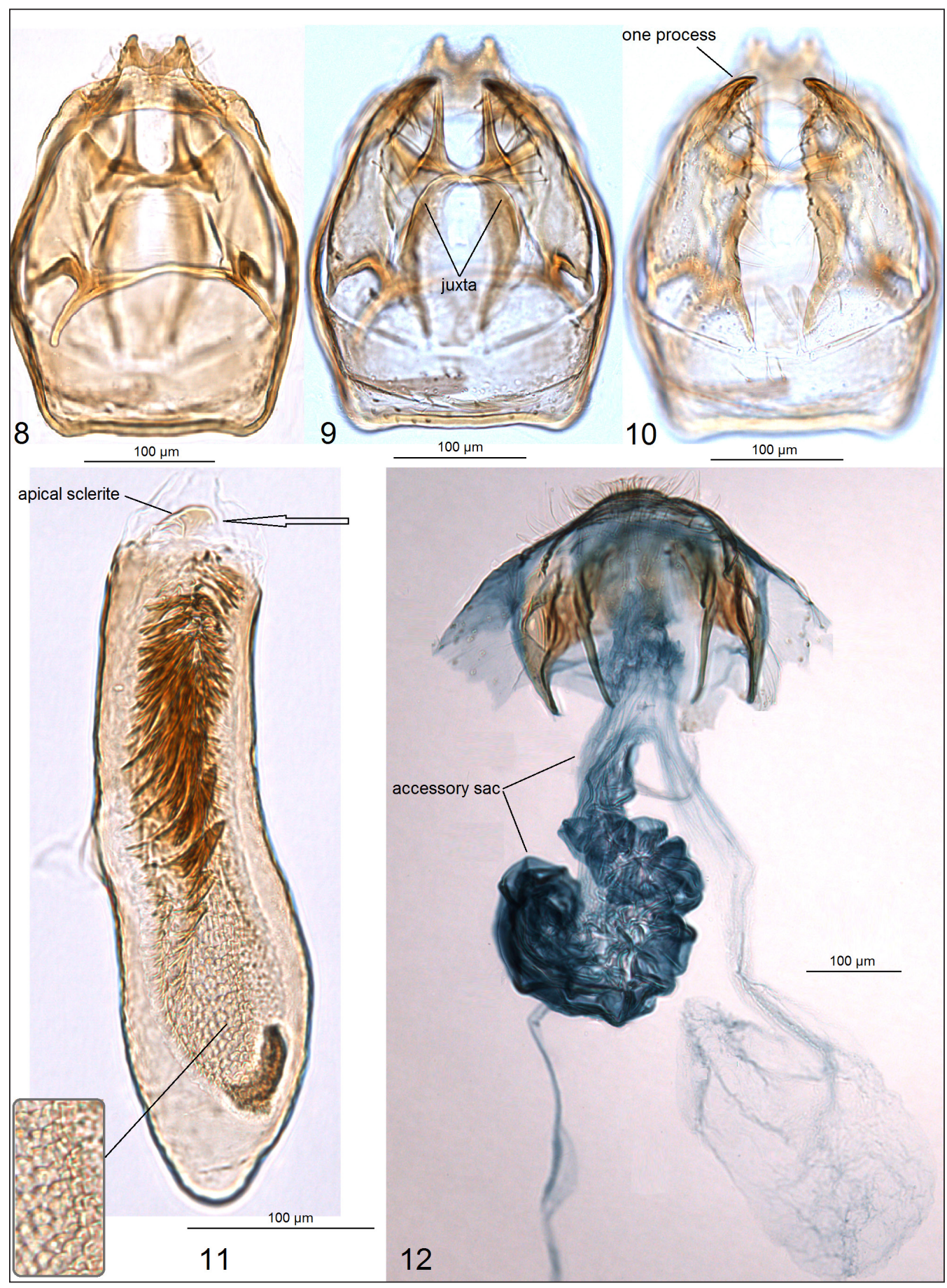

Figs. 8-12. Genitalia of Stigmella circinata Diškus \& Stonis, sp. nov. 8 - male genitalia, holotype, slide no. AD785, capsule with phallus removed; 11 - same, phallus; 12 - female genitalia, paratype, slide no. AD786 (ZMUC) 
Female genitalia (Fig. 12). Total length about $880 \mu \mathrm{m}$. Anterior and posterior apophyses almost equal in length; anterior apophyses slender distally; posterior apophyses very slender. Vestibulum without sclerites. Corpus bursae with slender, very little folded distal part and $350 \mu \mathrm{m}$ long basal body; signa absent; pectinations almost invisible or absent. Accessory sac very long and heavily folded; ductus spermathecae without coils or sclerites. Abdominal tip very wide, rounded.

Bionomics (Figs. 2-7). Host-plant: Hesperomeles obtusifolia (Pers.) Lindl (Rosaceae) (Figs. 2, 3). Larva pale yellow with pale ochre intestine and dark brown head; mines in leaves in January and, judging from observed numerous old (empty) leaf-mines, in December. Leaf-mine (Figs. 4-6) starts as a narrow gallery with an interrupted line of black-brown frass; later it develops abruptly into a large blotch with black-brown frass irregularly scattered, but most of it remains accumulated in the basal part of the blotch (Figs. 4, 5). Larva spins its cocoon outside of the mine. Cocoon dark beigebrown; length about $2.8 \mathrm{~mm}$, maximal width 1.5-1.6 mm. Exit slit on upper side of the leaf. According to the "Formula of Evaluation of Abundance and Occurrence of Leaf-Miners" (see Diškus, Stonis 2012: 52-54), Stigmella circinata is not a rare species: rather abundant mining of the new species was observed in two rather separated localities of the equatorial Andes in Ecuador.

Distribution (Figs. 1, 74). This species occurs in the Andes of Ecuador in tropical montane and cloud forests at altitudes of about 2800-3100 m.

Etymology. The species name is derived from the Latin circinatus (rounded) in reference to the rounded shape of the male genital capsule, juxta, the blotch-like mine, and rather rounded leaves of the host-plant.

Remarks. Stigmella circinata represents a very distinctive species. Because of the urgency to name this species for further taxonomic and trophic analysis, Stigmella circinata, as an exception, was described on the basis of the highly specific male and female genita- lia and leaf-mines. Details of male and female adult scaling remain unknown because all currently available type series specimens were dissected from adults in a pupal skin and accidentally no pinned specimens were preserved.

\section{Stigmella rubiphagiella Diškus \& Stonis, sp. nov.}

Type material. Holotype: $\hat{\jmath}$, ECUADOR: Pichincha Province, $11 \mathrm{~km}$ NW Alóag, $0^{\circ} 26^{\prime}$ 45"S, 78 37'34"W, elevation $3090 \mathrm{~m}$, mining larvae on Rubus sp. (Rosaceae), 12.i.2005, field card no. 4810, A. Diškus \& J. R. Stonis, genitalia slide no. $\mathrm{AD} 760{ }^{\lambda}$ (from an adult in pupal skin) (ZMUC).

Diagnosis. The combination of a specific gnathos (see Fig. 17); valva with two distinctive, pointed processes; long lobes of vinculum; large uncus; specific set of cornuti (see Figs. 20, 21); specific leaf-mine (see Fig. 15); and a slender, beige-white cocoon inside of the leaf-mine distinguishes S. rubiphagiella sp. nov. from all other Stigmella species, including all members of the S. imperatoria group.

Male (See Remarks).

Female. Unknown.

Male genitalia (Figs. 16-21). Capsule significantly longer (380-285 $\mu \mathrm{m})$ than wide $(200 \mu \mathrm{m})$. Uncus very wide, with lobes. Gnathos almost U-shaped, with two caudal processes and very slender central plate. Valva $240-245 \mu \mathrm{m}$ long, 55-65 $\mu \mathrm{m}$ wide, with two distinctive apical processes; transtilla without sublateral processes. Juxta almost membranous, indistinctive (Fig. 16). Vinculum with very large lateral lobes. Phallus (Figs. 20, 21) $270 \mu \mathrm{m}$ long, 70-80 $\mu \mathrm{m}$ wide; vesica with unique set of cornuti comprising 2-3 clusters of spine-like cornuti.

Bionomics (Figs. 13-15). Host-plant: Rubus sp. (Rosaceae) (Figs. 2, 3). Larva pale brownish yellow with brown intestine and dark brown head; mines in leaves in January. Leafmine (Figs. 13, 15) reminds of a large elongated blotch with black-brown frass scattered irregularly (Figs. 4, 5). Larva spins its cocoon inside of the mine. Shape of the cocoon rather unusual, narrow; length about $2.4 \mathrm{~mm}$, maximal width about $1 \mathrm{~mm}$. Exit slit on upper side of the leaf. According to the "Formula of Evaluation of 

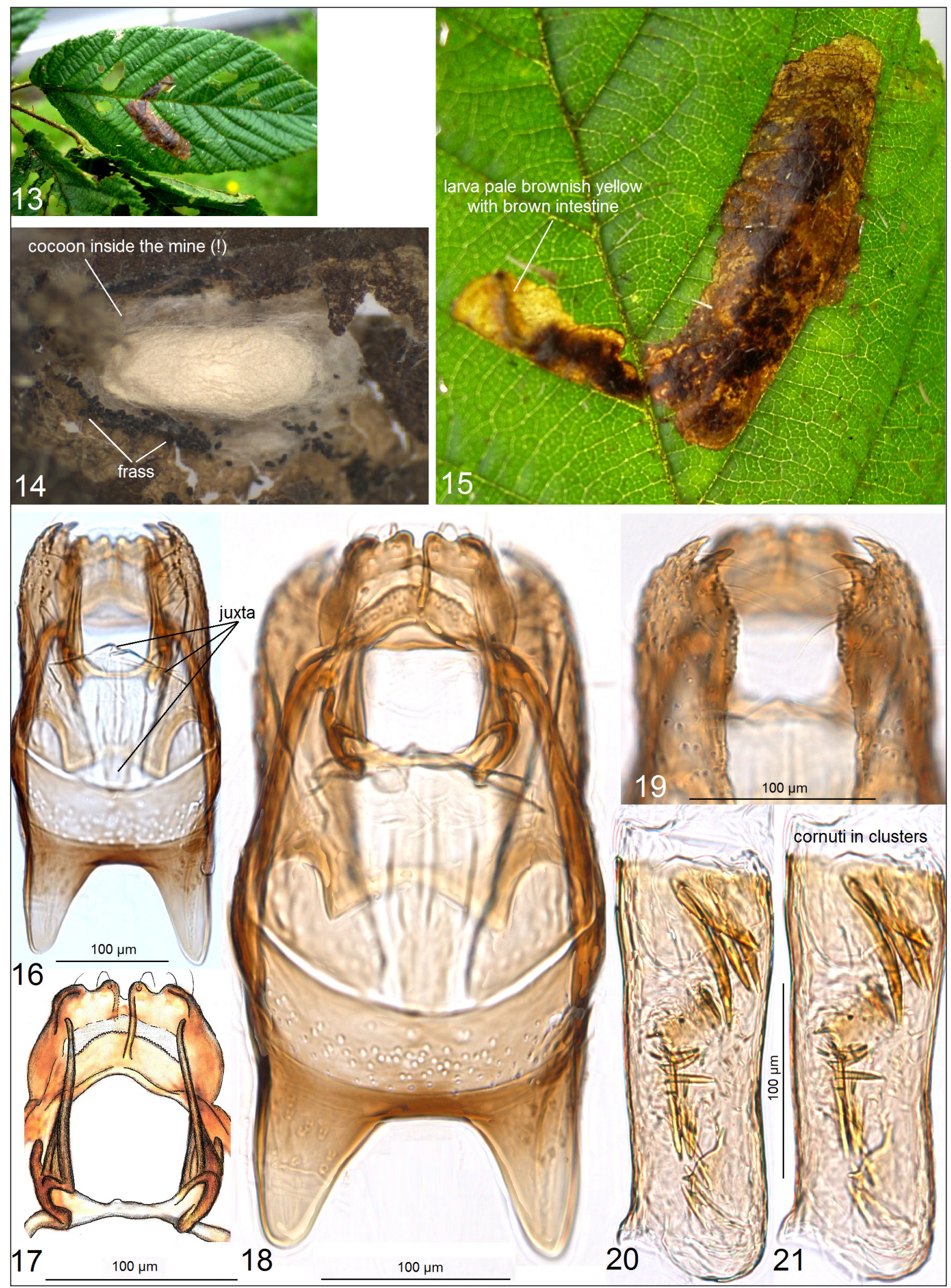

Figs. 13-21. Stigmella rubiphagiella Diškus \& Stonis; 13, 15 - leaf-mine; 14 - cocoon; 16-19 - male genitalia, genitalia slide no. AD760, holotype, details of capsule with phallus removed (ZMUC); 20, 21 - same, phallus 
Abundance and Occurrence of Leaf-Miners" (see Diškus, Stonis 2012: 52-54), Stigmella rubiphagiella is a rare species: it has been observed only in a single locality and is characterized by very scanty mining (2-3 leaf-mines).

Distribution (Fig. 74). This species occurs in the equatorial Andes (Ecuador: Pichincha Province) in tropical montane or cloud forests at the altitude of about $3100 \mathrm{~m}$.

Etymology. The species is named after the host-plant genus Rubus L. combining Latin Rubus (blackberries, dewberries) with phagus (an eater), in reference to the feeding habit of the larvae of S. rubiphagiella.

Remarks. Stigmella rubiphagiella represents a distinctive species. Because of the urgency to name this species for further taxonomic and trophic analysis, Stigmella rubiphagiella, as an exception, was described on the basis of the specific male genitalia and leaf-mines. Details of male adult scaling remain unknown because the holotype was dissected from adult in a pupal skin and accidentally no pinned specimen was preserved.

\section{Stigmella nubimontana Puplesis \& Diškus, 2002}

Material examined. $1 \hat{\sigma}, 2$, ECUADOR: Pichincha Province, $11 \mathrm{~km}$ NW Alóag, $0^{\circ} 26^{\prime}$ 44"S, 78 37'36"W, elevation $3085 \mathrm{~m}$, mining larvae on Rubus sp. (Rosaceae), 12.i.2005, field card no. 4809, A. Diškus \& J. R. Stonis, genitalia slides nos. AD790今̂, AD827우, AD828우 (ZMUC).

Remarks. The species was described by $\mathrm{Pu}-$ plesis and Diškus (Puplesis et al., 2002) exclusively on the basis of male material collected in Papallacta, Ecuador. In this paper we provide photographs of discovered females for the first time (Figs. 22, 26); we also provide the first photographic documentation of male genitalia and leaf-mines (Figs. 65, 66) and add new distribution data from Alóag, Pichincha Province, Ecuador.

\section{Stigmella rubeta Puplesis \& Diškus, 2002}

Material examined. $2 \hat{\sigma}, 1$, ECUADOR: Pichincha Province, Tandapi, $0^{\circ} 25^{\prime} 26^{\prime \prime}$, $78^{\circ} 47^{\prime} 44^{\prime \prime} \mathrm{W}$, elevation $1550 \mathrm{~m}$, mining larvae on Rubus sp. (Rosaceae), 8.i.2005, field card no. 4798, A. Diškus \& J. R. Stonis, genitalia slides nos. AD799ð, AD837ð (ZMUC).

Remarks. The species was described by Puplesis and Diškus (Puplesis et al., 2002). In this paper, we provide the first photographic documentation of the female adult (Fig. 27), male genitalia (Figs. 28, 29), and the leaf-mines (Figs. 67, 68).

\section{Ectoedemia (Ectoedemia) morae Diškus \& Stonis, sp. nov.}

Type material. Holotype: $q$, ECUADOR: Pichincha Province, $11 \mathrm{~km}$ NW Alóag, $0^{\circ} 26^{\prime}$ 46"S, 78 37'38"W, elevation $3095 \mathrm{~m}$, mining larvae on Rubus sp. (Rosaceae), 18.xi.2007, field card no. 4924, A. Diškus, genitalia slide no. AD838 9 (ZMUC). Paratypes: 2 Ô, 1 , same label data as holotype, genitalia slides nos. AD803 $\hat{\jmath}, A D 817 \hat{\jmath}, A D 797 \bigcirc$ (ZMUC).

Diagnosis. Belongs to the angulifasciella group of the subgenus Ectoedemia Busck. The combination of a wide, distally rounded caudal process of gnathos in the male genitalia, ductus spermathecae with $4.5-5$ coils in the female genitalia, black rounded cocoon, and a very shiny forewing of the adult distinguishes S. morae sp. nov. from all other Ectoedemia species, including the most related members of the E. angulifasciella group.

Male. Similar to female, however, antenna slightly longer, scaling tends to be slightly darker and less shiny to compare with female (see Remarks).

Female (Fig. 37). Forewing length about $2.0 \mathrm{~mm}$; wingspan about $4.5 \mathrm{~mm}$. Head: palpi grey, glossy; frontal tuft pale ferruginous; collar indistictive, comprised of piliform scales; scape golden cream with blue iridescence; antenna as long as half the length of forewing; flagellum with 27-28 segments, black-grey to dark grey on upper side and underside. Thorax and tegula black-brown with strong blue iridescence. Forewing with three areas densely speckled with black-brown scales (at certain angle of view - with light or strong golden gloss and some purple iridescence), and three areas 


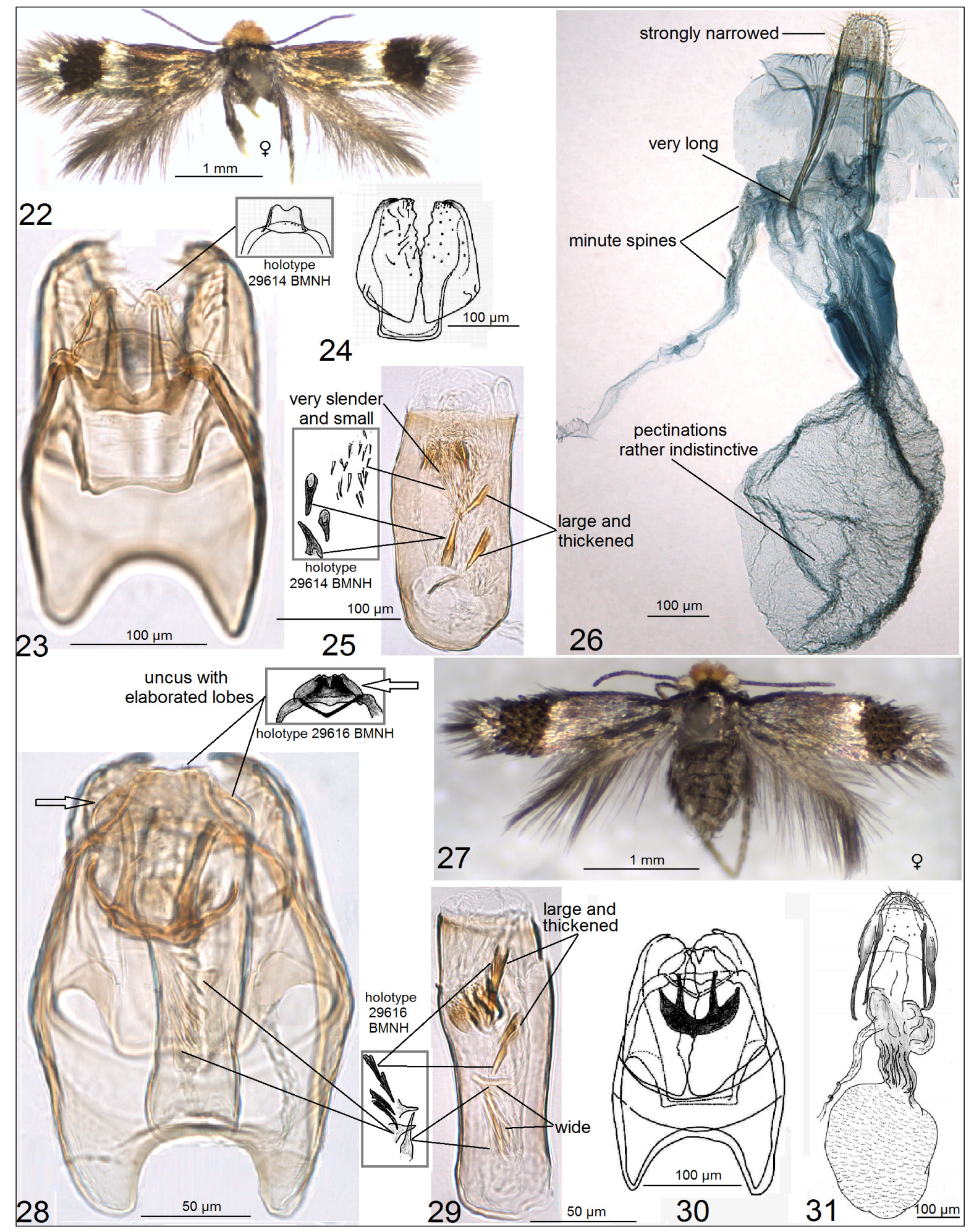

Figs. 22-31. Rubus-feeding species. 22 - Stigmella nubimontana Diškus \& Stonis, female adult AD828 (ZMUC); 23 - same, male genitalia, slide no. AD790; 24 - same, valvae, holotype, after Puplesis et al., 2002 (BMNH); 25 - same, phallus, slide no. AD790 (ZMUC); 26 - same, female genitalia, slide AD828; 27 - Stigmella rubeta Diškus \& Stonis, female adult (ZMUC); 28 - same, male genitalia, slide AD799 (ZMUC); 29 - same, phallus, slide no. AD837; 30 - same, male genital capsule, holotype, after Puplesis et al., 2002 (BMNH); 31 - same, female genitalia, paratype, after Puplesis et al., 2002 (BMNH) 

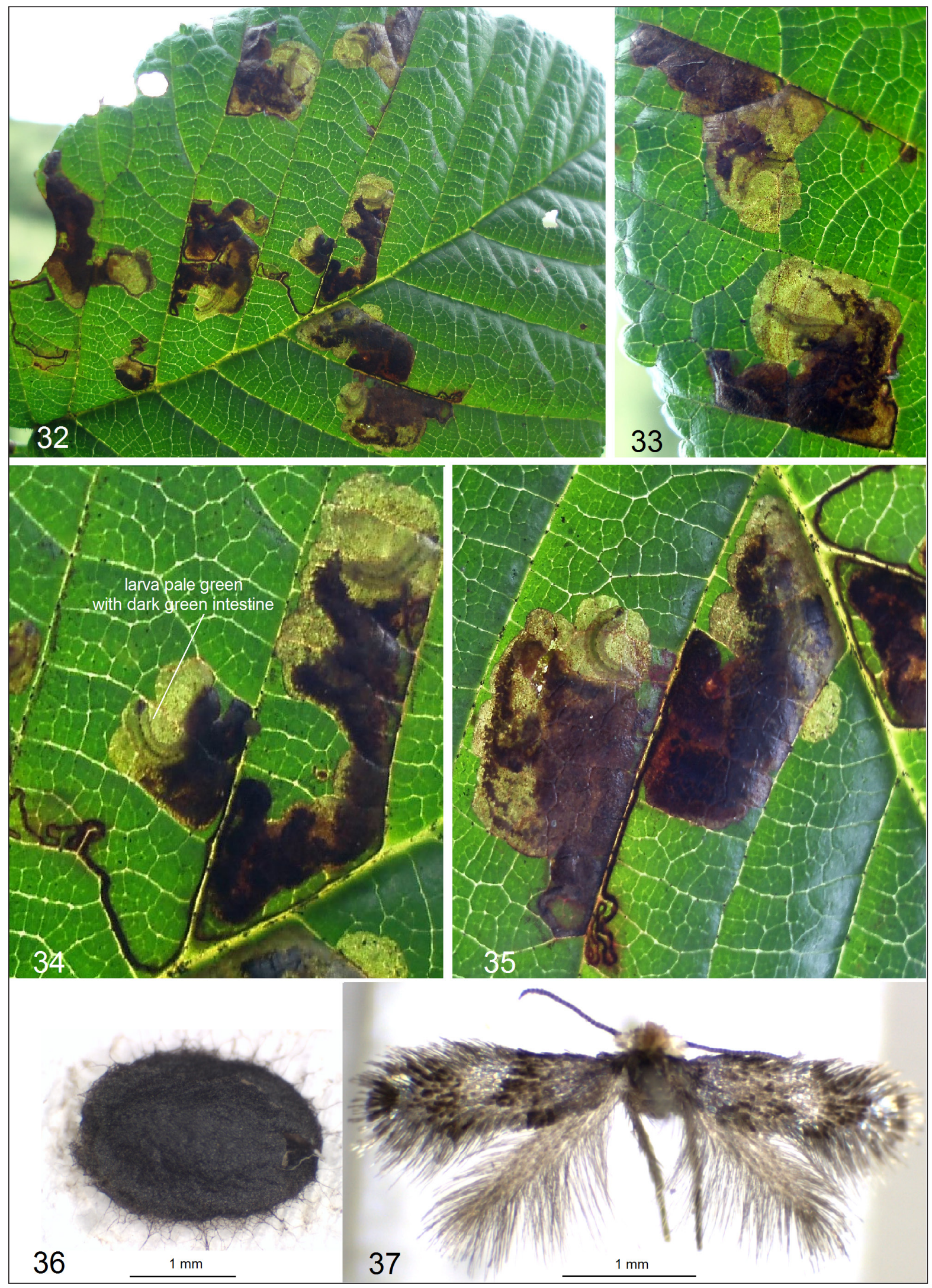

Figs. 32-37. Ectoedemia morae Diškus \& Stonis, sp. nov. 32-35 - leaf-mines; 36 - cocoon; 37 - female adult, holotype (ZMUC) 


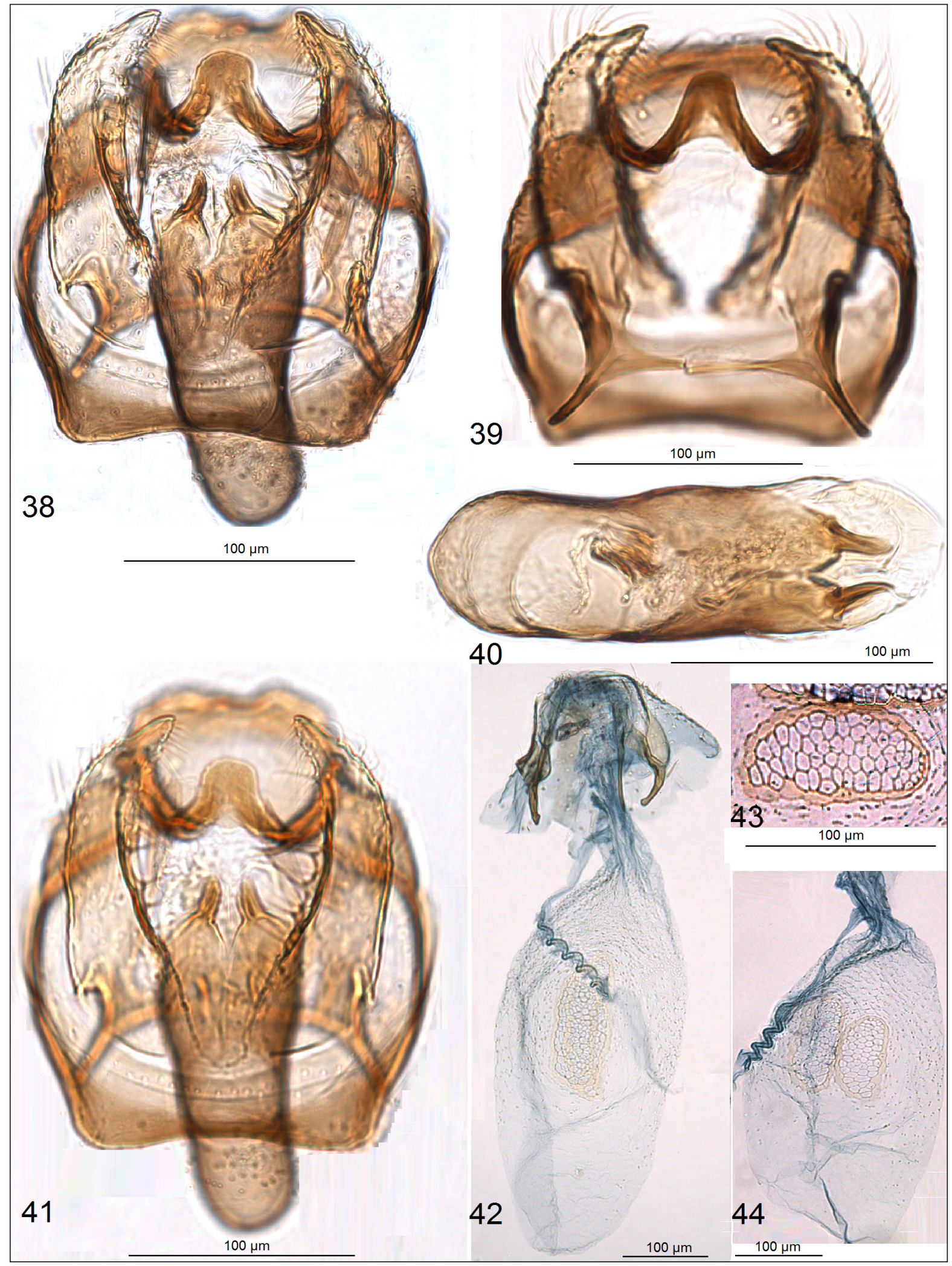

Figs. 38-44. Genitalia of Ectoedemia morae Diškus \& Stonis, sp. nov. 38 - male genitalia, slide no. AD817, paratype; 39 - capsule of male genitalia, slide no. AD803, paratype; 40 - same, phallus; 41 - male genitalia, slide no. AD817, paratype; 42 - female genitalia, slide no. AD838, holotype; 43 - signum, slide no. AD797, paratype; 44 - same, bursa copulatrix and ductus spermathecae (ZMUC) 
(fasciae) of silvery shiny scales with blue ireidescence; fringe grey with strong golden gloss; underside of forewing brown-black, without spots. Hindwing grey with light purple and blue iridescence on upper side, dark grey on underside, without spots; its fringe grey with some golden gloss distally. Legs brownish grey to dark grey with some purple iridescence on upper side and underside, except hindlegs which covered in brown-black scales on upper side. Abdomen dark grey, very glossy.

Male genitalia (Figs. 38-41). Capsule rounded, $185 \mu \mathrm{m}$ long, $190 \mu \mathrm{m}$ wide. Uncus short but wide. Gnathos V-shaped, with one large, distally rounded apical process. Valva 135-160 $\mu \mathrm{m}$ long, 40-55 $\mu \mathrm{m}$ wide, with one apical process; inner lobe not bulged; transtilla with long sublateral processes. Vinculum very short, without lateral lobes. Phallus (Fig. 40) 190-200 $\mu \mathrm{m}$ long, 50$70 \mu \mathrm{m}$ wide.

Female genitalia (Figs. 42-44). Total length 705-760 $\mu \mathrm{m}$. Anterior and posterior apophyses almost equal in length. Vestibulum without sclerites. Corpus bursae $500 \mu \mathrm{m}$ long, $230 \mu \mathrm{m}$ wide, with distinctive but rather sparse pectinations (except the basal part) and with two asymmetrical signa (Figs. 43, 44). Ductus spermathecae without 4.5-5 coils. Abdominal tip very wide, rounded or truncated.

Bionomics (Figs. 32-36). Host-plant: Rubus sp. (Rosaceae). Larva pale green with dark green intestine and brown-black head; mines in November. Leaf-mine (Figs. 32-35) starts as a narrow gallery entirely filled with black-brown frass; further on it develops abruptly into a large blotch with black-brown frass compactly accumulated in basal part of the blotch. Larva spins its cocoon outside of the mine. Cocoon almost black, slightly glossy, rounded; length about $2.2 \mathrm{~mm}$, maximal width $1.7 \mathrm{~mm}$. Exit slit on upper side of the leaf. According to the "Formula of Evaluation of Abundance and Occurrence of Leaf-Miners" (see Diškus, Stonis 2012: 52-54), Ectoedemia morae is not a rare species: very abundant mining of the new species has been observed, though only in a single locality.

Distribution (Figs. 1, 74). This species occurs in the Andes of Ecuador in tropical mon- tane and cloud forests at altitudes of about 2800-3100 m.

Etymology. The species name is derived from the Spanish name of the host-plant (mora).

Remarks. The type series is comprised of five specimens: three males (paratypes) and two females (holotype and paratype). In the species description, contrary to common practice, details of the scaling were described on the female holotype (not male) because the female holotype specimen was much better preserved (not rubbed) in comparison with the male specimens: one male specimen was slightly rubbed (and placed into a plastic tube) and the remaining two specimens were dissected from adults in a pupal skin; therefore, not a single adult of these specimens has been preserved for collection (only genitalia slides).

Documentation of the newly discovered leaf-
mines of Nepticulidae on Rosaceae plants
Leaf-mines on Prunus (possibly P. huatensis
Pilger)
ECUADOR, Loja Province, about $13-20 \mathrm{~km} \mathrm{SE}$ Loja, Podocarpus National Park, near Cajanuma centre and refugio, $4^{\circ} 04^{\prime} 53^{\prime \prime} \mathrm{S}, 79^{\circ} 09^{\prime} 55^{\prime \prime} \mathrm{W}$, elevation about $2200 \mathrm{~m}$ (Fig. 74).

Larvae pale yellow with bright green intestine; mine in February and, judging from observed vacant leaf-mines, in January. Leaf-mine reminds of a gradually widening, sinuous, or strongly contorted gallery (Figs. 47-49). Larval exit slit on upper side of the leaf. The documented leaf-mines belong to an unknown Nepticulidae species (possibly to the genus Stigmella Schrank).

\section{Leaf-mines on Hesperomeles obtusifolia}

(Pers.) Lindl

ECUADOR, Pichincha Province, $45 \mathrm{~km}$ E Quito, $0^{\circ} 16^{\prime} 07^{\prime \prime S}, 78^{\circ} 16^{\prime} 25^{\prime \prime} \mathrm{W}$, elevation $3290 \mathrm{~m}$ (Fig. 74).

Larvae yellow; mine in January. Leaf-mine (Figs. 52, 53) reminds of a slender, slightly widening, sinuous gallery (not widening into a blotch as in Stigmella circinata sp. nov. (Figs. 4, 5). Larval exit slit on upper side of the leaf. The documented leaf-mines belong to an unknown Stigmella taxon. 

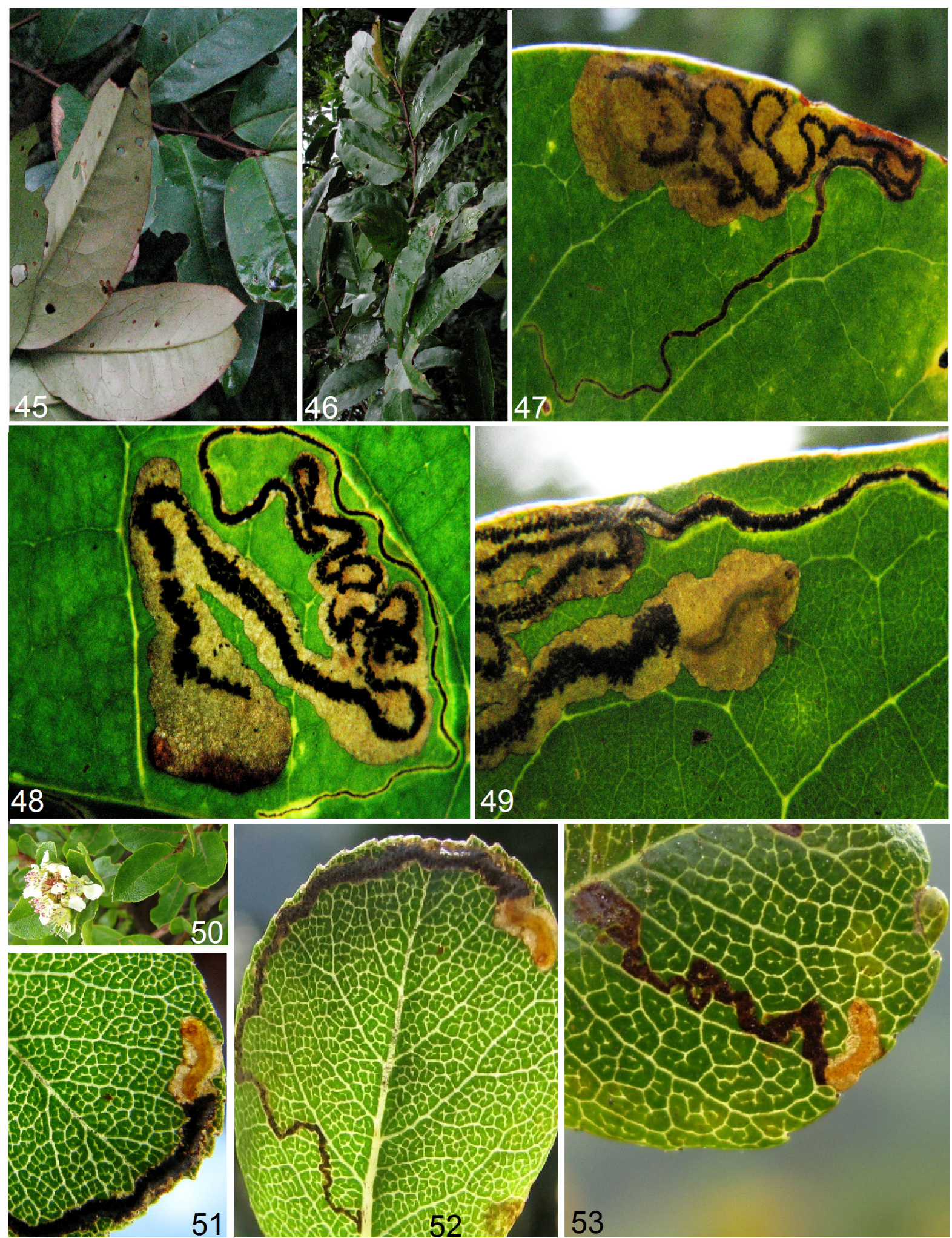

Figs. 45-53. Documentation of leaf-mines of unknown Nepticulidae taxa on Prunus L. and Hesperomeles Lindl. 45, 46 - host-plant Prunus (possibly P. huatensis Pilger); 47-49 - leaf-mines on Prunus sp. (possibly P. huatensis Pilger), Ecuador, SE Loja, 404'53"S, 7909'55"W, elevation about $2200 \mathrm{~m}$; 50, - host-plant Hesperomeles obtusifolia (Pers.) Lindl; 51-53 - leaf-mines on H. obtusifolia, Ecuador, $45 \mathrm{~km}$ E Quito, $0^{\circ} 16^{\prime} 07^{\prime \prime S}$, $78^{\circ} 16^{\prime} 25^{\prime \prime} \mathrm{W}$, elevation $3290 \mathrm{~m}$ 


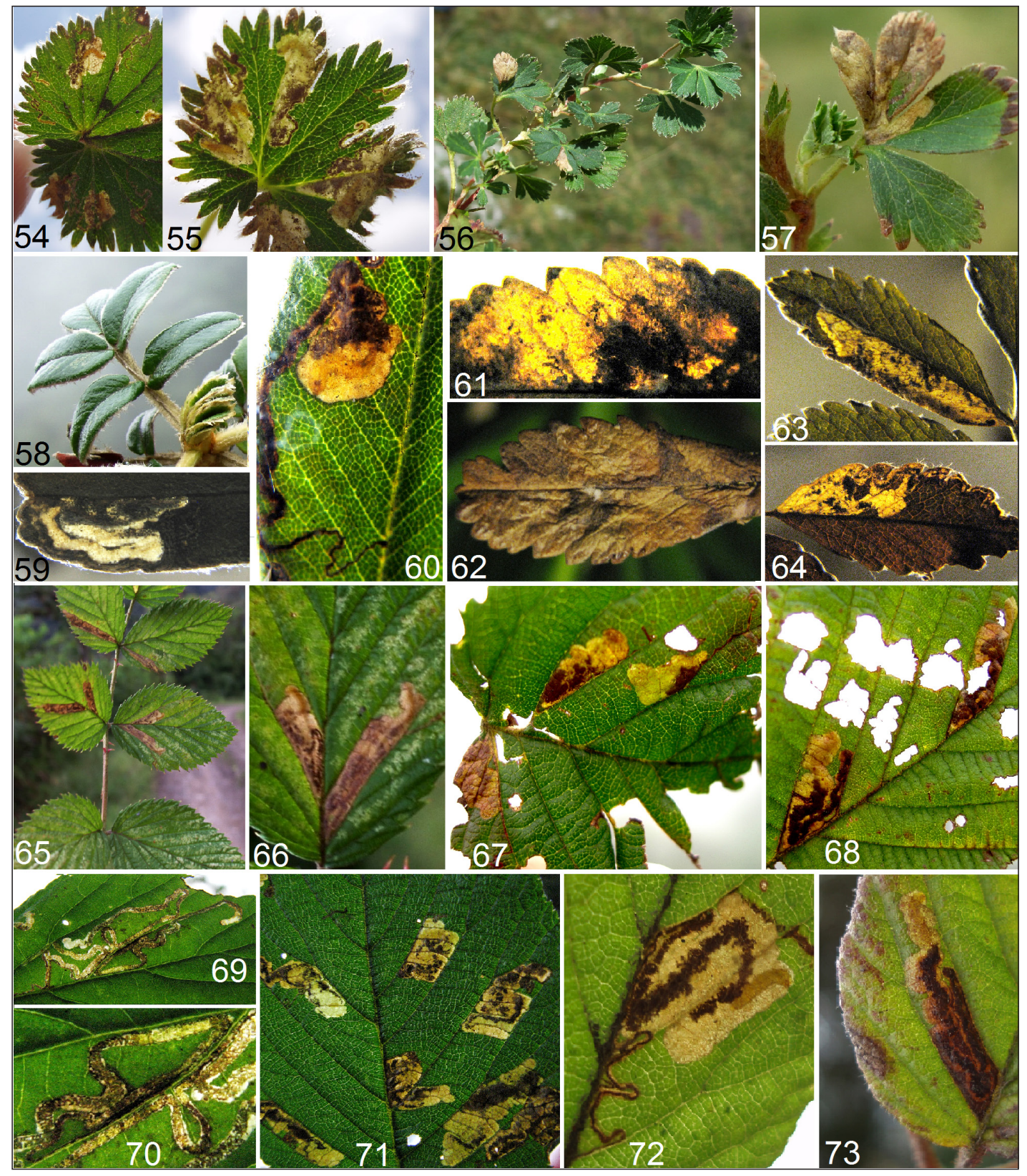

Figs. 54-73. Documentation of leaf-mines. 54, 55 - Stigmella lachemillae Diškus \& Stonis on Lachemilla orbiculata (Ruiz \& Pav.) Rydb., Ecuador, 25 km NW Riobamba, 1³1'20"S, 78 50'27"W, $3980 \mathrm{~m} ; 56$ - host-plant Alchemilla procumbenscens; 56, leaf-mines on A. procumbescens, Ecuador, $30 \mathrm{~km}$ NE Pallatanga, $1^{\circ} 52^{\prime} 41^{\prime \prime} \mathrm{S}, 78^{\circ} 54^{\prime} 11^{\prime \prime} \mathrm{W}, 3025$ m; 58 - host-plant Polylepis pauta Hieron.; 59 - leaf-mines on Polylepis racemosa Ruiz \& Pav. Peru, Junin Province, Ondores, elevation $4100 \mathrm{~m} ; 60$ - leaf-mine of Stigmella species 763 or S. species 764 (see Stonis et al., 2016); 61, 62 - Stigmella polylepiella Diškus \& Stonis on Polylepis racemosa Ruiz \& Pav., Peru, NW of Cuzco, $13^{\circ} 15^{\prime} 31^{\prime \prime} \mathrm{S}, 72^{\circ} 15^{\prime} 54^{\prime \prime} \mathrm{W}, 2850 \mathrm{~m}$; 63, 64 - leaf-mines on Acaena elongata L., Ecuador, NW Riobamba, $1^{\circ} 31^{\prime} 20^{\prime \prime} \mathrm{S}, 78^{\circ} 50^{\prime} 27^{\prime \prime} \mathrm{W}, 3900$ m; 65, 66 - Stigmella nubimontana Diškus \& Stonis on Rubus sp., Ecuador, $11 \mathrm{~km} \mathrm{NW}$ Alóag, $0^{\circ} 26^{\prime} 44^{\prime \prime} \mathrm{S}, 78^{\circ} 37^{\prime} 36^{\prime \prime} \mathrm{W}, 3085$ m; 67, 68 - Stigmella rubeta Diškus \& Stonis on Rubus sp., Ecuador, Tandapi, $0^{\circ} 25^{\prime} 26^{\prime \prime} \mathrm{S}, 78^{\circ} 47^{\prime} 44^{\prime \prime} \mathrm{W}, 1550 \mathrm{~m}$; 69, 70 - leaf-mines on Rubus sp., Colombia, Parque Chicaque, $4^{\circ} 36^{\prime} 21^{\prime \prime} N$, 74 $4^{\circ} 18^{\prime} 24^{\prime \prime}$ W, 2550 m; 71 - leaf-mines on Rubus sp., Ecuador, SE Loja, $4^{\circ} 04^{\prime} 53^{\prime \prime S}$, 7909'55"W, 2200 m; 72, 73 - leaf-mines on Rubus niveus Thunb., Ecuador, Baños, $1^{\circ} 23^{\prime} 44^{\prime \prime} \mathrm{S}, 78^{\circ} 26^{\prime} 14^{\prime \prime} \mathrm{W}, 1855-2200 \mathrm{~m}$ 


\section{Leaf-mines on Alchemilla procumbescens}

ECUADOR, Chimborazo Province, ca. $30 \mathrm{~km}$ NE Pallatanga, $1^{\circ} 52^{\prime} 41^{\prime \prime S}, 78^{\circ} 54^{\prime} 11^{\prime \prime} \mathrm{W}$, elevation $3025 \mathrm{~m}$ (Fig. 74).

Larvae yellow; mine in January. Leaf-mine (Fig. 57) reminds of a slender gallery widening into a blotch. Larval exit slit on upper side of the leaf. The documented leaf-mines belong to an unknown Stigmella taxon, possibly related but different from the other Ecuadorian Andean species S. lachemillae Diškus \& Stonis (Figs. 54, 55).

\section{Leaf-mines on Acaena elongata L.}

ECUADOR, Chimborazo Province, $25 \mathrm{~km} \mathrm{NW}$ Riobamba, $1^{\circ} 31^{\prime} 20^{\prime \prime} \mathrm{S}, 78^{\circ} 50^{\prime} 27^{\prime \prime} \mathrm{W}$, elevation about $3900 \mathrm{~m}$ (Fig. 74).

Larvae pale yellow with brown heads; mine in early January and, judging from observed vacant leaf-mines, in December. Leaf-mine (Figs. 63, 64) reminds of a slender gallery with a wide interrupted line of brown-black frass; further the gallery widens into a large blotch. Larval exit slit on upper side of the leaf. The documented leaf-mines belong to an unknown Stigmella taxon.

\section{Leaf-mines on Rubus sp.}

COLOMBIA, Cundinamarca Department, San Antonio del Tequendama municipality, Parque Chicaque, $4^{\circ} 36^{\prime} 21^{\prime \prime} \mathrm{N}, 74^{\circ} 18^{\prime} 24^{\prime \prime} \mathrm{W}$, cloud forest, elevation $2550 \mathrm{~m}$ (Fig. 74).

Larvae mine in early February and, judging from observed vacant leaf-mines, in January. Leaf-mine (Figs. 63, 64) reminds of a long slender gallery almost entirely filled with browngreen and green frass. Larval exit slit on upper side of the leaf. The documented leaf-mines belong to an unknown Stigmella taxon.

\section{Leaf-mines on Rubus sp.}

ECUADOR, Loja Province, about 13-20 km SE Loja, Podocarpus National Park, near Cajanuma centre and refugio, $4^{\circ} 04^{\prime} 53^{\prime \prime} \mathrm{S}, 7^{\circ} 09^{\prime} 55^{\prime \prime} \mathrm{W}$, elevation about $2200 \mathrm{~m}$ (Fig. 74).

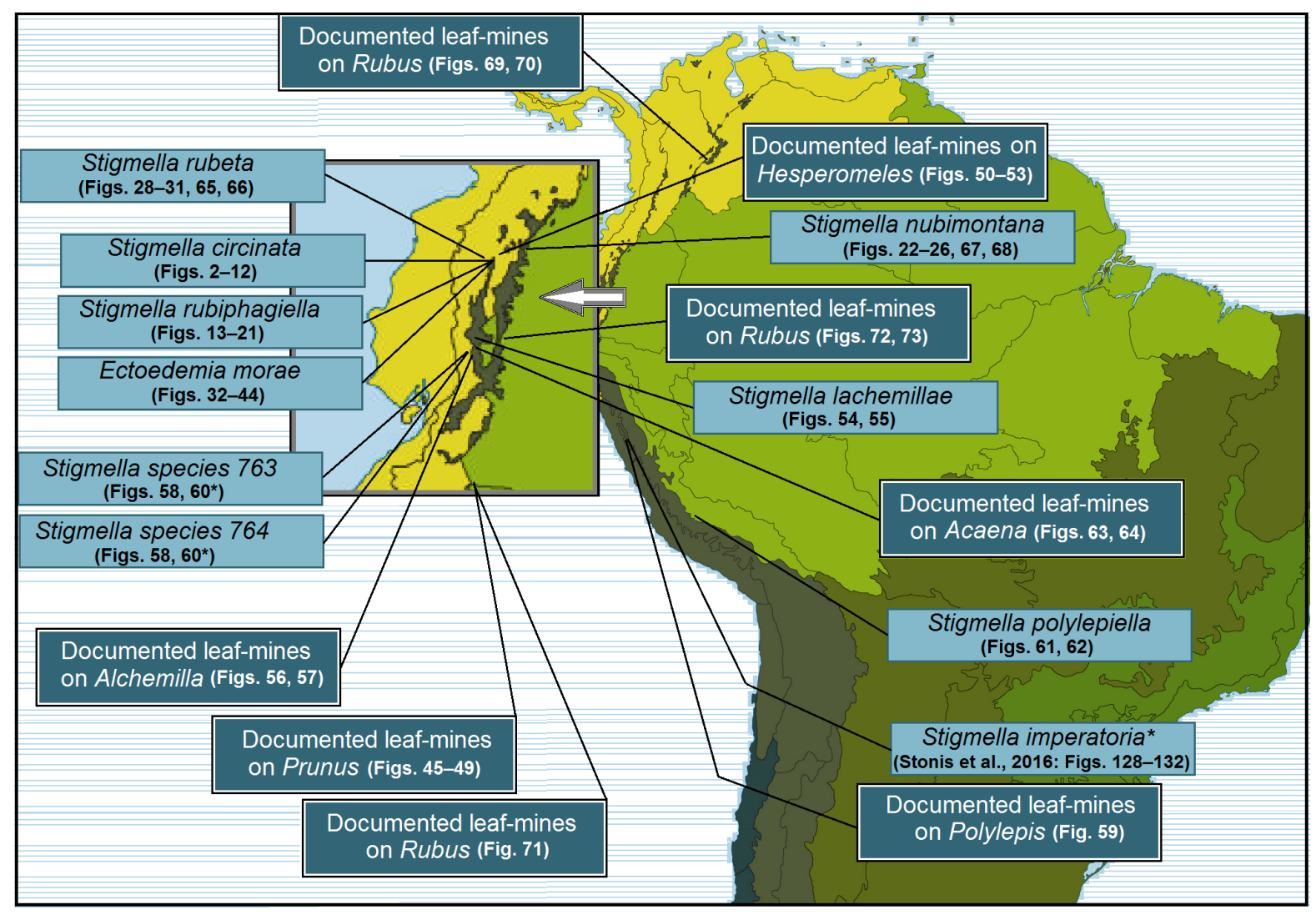

Fig. 74. Records of the Rosaceae-mining Nepticulidae in South America; ${ }^{\star}$ - it expected to be a Polylepisfeeding species (for this reason, $S$. imperatoria was included in the current review) 


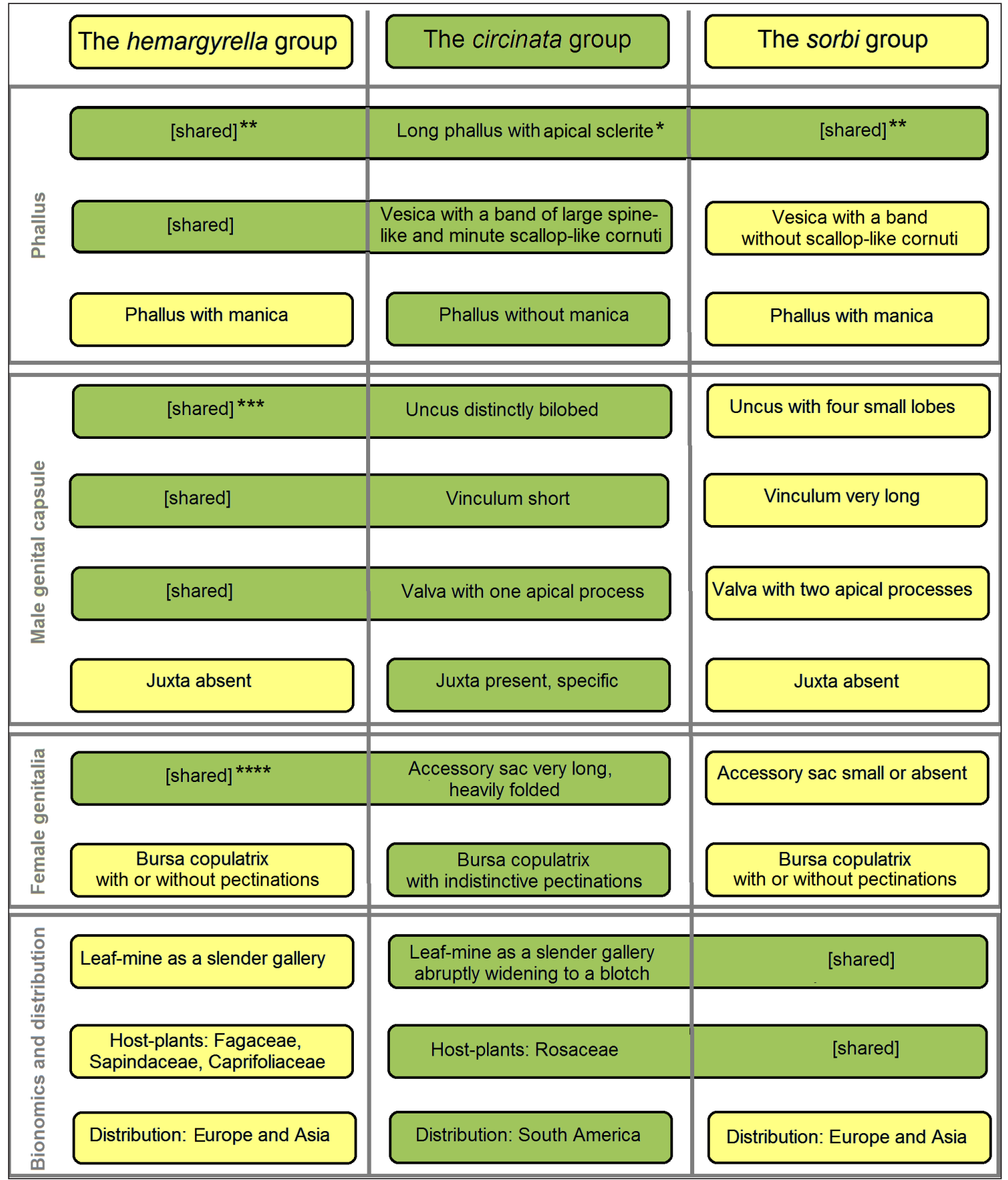

Fig. 75. Diagnostics of the Stigmella circinata species group ( ${ }^{*}-$ possibly a synapomorphic character; however, a phylogenetic analysis is needed; ${ }^{* *}$ - apical sclerite may be absent in some species; ${ }^{* *}$ - except S. speciosa (Frey); ${ }^{* * *}$ - except S. speciosa (Frey) and S. hemargyrella (Kollar, 1832))

Larvae mine in early February and, judging from observed numerous vacant leaf-mines, in January. Leaf-mine starts as very slender and short gallery entirely filled with blackish green or black frass; further on the gallery abruptly widens into a blotch with irregularly scattered black frass (Fig. 71). Larval exit slit on upper side of the leaf. The documented leaf-mines belong to an unknown Stigmella taxon.

\section{Leaf-mines on Rubus niveus Thunb.}

ECUADOR, Tungurahua Province, Baños, $1^{\circ} 23^{\prime} 44^{\prime \prime} \mathrm{S}, 78^{\circ} 26^{\prime} 14^{\prime \prime} \mathrm{W}$, elevation 1855-2200 m (Fig. 74). 
Larvae pale yellow with pale brown heads; mine in early February and, judging from observed vacant leaf-mines, in January. Leaf-mine starts as a very slender and long sinuous gallery with a line of black-brown frass; further on the gallery gradually widens (Figs. 72, 73). Larval exit slit on upper side of the leaf. The documented leaf-mines belong to an unknown Stigmella taxon, possibly related but different from the other Ecuadorian Andean Rubus-feeding species S. nubimontana Puplesis \& Diškus (see Figs. 67, 68).

\section{DISCUSSION}

The Rosaceae-feeding fauna. In the Holarctics, the Rosaceae-feeding Nepticulidae form a very large fraction (about 100 species, 28\%) of the trophically studied species of the pygmy moths family (Remeikis et al., 2016), whereas in the Neotropics, the Rosaceae-mining Nepticulidae are based only on 18 records, which currently include ten species, eight of which are named (Ectoedemia morae Diškus \& Stonis, sp. nov.; Stigmella lachemillae Diškus \& Stonis; S. rubeta Puplesis \& Diškus; S. nubimontana Puplesis \& Diškus; S. circinata Diškus \& Stonis, sp. nov.; S. rubiphagiella Diškus \& Stonis, sp. nov.; S. polylepiella Diškus \& Stonis; and possibly S. imperatoria Puplesis \& Robinson) and two unnamed (S. species 763 and $S$. species 764). We assume that the relatively low number of species trophically associated with Rosaceae plants can be explained not only by unsufficient collecting but also by two other reasons: (1) specific, partially restricted, distribution of the host-plant family in South America, (2) largely in contrast to the Holarctic fauna, distinctive predominance of Asteraceae-feeders in the Neotropical or even Ando-Patagonian fauna (Remeikis et al., 2016).

It is not surprising that all currently known records of the Rosaceae-feeding Nepticulidae come from the Andes of Colombia, Ecuador, and Peru (Fig. 74) because in South America, the host-plant family is characterized by rather low species diversity in the moist tropical forest (including the rainforest) and the American de- serts. The Rosaceae-feeding fauna described in this paper is undeniably only the tip of an iceberg.

The currently known range of host-plants of the Rosaceae-feeding Nepticulidae includes seven genera of the rose family: Lachemilla Rydb. (one nepticulid species), Alchemilla (one unknown taxon judging from the documented leaf-mines; Figs. 56, 57), Acaena L. (one unknown taxon judging from documented the leaf-mines; Figs. 63, 64), Hesperomeles Lindl. (one nepticulid species and one unknown taxon judging from the documented leaf-mines; Figs. 51-53), Prunus L. (one unknown taxon judging from the documented leaf-mines; Figs. 47-49), and Polylepis Ruiz \& Pav. (three or four species and one unknown taxon judging from the documented leaf-mine; Fig. 59). However, most of the leaf-mining Nepticulidae species feed on Rubus L. (four nepticulid species and three unknown taxa judging from the documented leaf-mines; Figs. 69-73).

Taxonomic diversity. Generic composition of this Rosaceae-feeding fauna is rather uniform: except for one (Ectoedemia morae), all other species belong to the genus Stigmella Schrank. The dominance of Stigmella among the Rosaceae-feeders in South America is probably not an artefact. This genus is the world's largest and most widespread genus of Nepticulidae, occurring from the tundra and boreal forests to tropical rainforests or semideserts. Among the discovered Stigmella species associated with Rosaceae, some are rather similar and, therefore, are likely to be closely related. For diagnostic purposes, such clusters of similar species are traditionally named as species groups, i. e. Stigmella lachemillae, S. nubimontana, and S. rubeta are attributed to two different species groups errected in a forthcoming paper (Stonis et al., in prep.); S. polylepiella, S. imperatoria, and S. rubiphagiella, to the newly designated $S$. imperatoria group; see below.

However, the discovered Rosaceae-feeding Stigmella species generally exhibit a remarkable range of morphological structures, particularly S. species 763 and S. species 764: they have not been attributed to any species group yet and are awaiting additional research (including molecular studies). 


\section{Designation of the Stigmella imperatoria} group. Diagnostics: forewing very glossy. In male genitalia, phallus with specific cluster(s) of small cornuti; valva with one or two apical processes; uncus with three to four caudal papillae; gnathos with two long and slender, closely juxtaposed or separated caudal processes and medially slender plate; vinculum with large lateral lobes. Currently the group comprises three closely similar but still clearly different Andean species: one from Ecuador (Stigmella rubiphagiella) and two from Peru (S. imperatoria and S. polylepiella). Trophic relationships: two species are known as leafminers on Rubus and Polylepis (Rosaceae). It is assumed that all the species of the group might be Rosaceae feeders, including S. imperatoria, which probably is a Polylepis-feeding species (for this reason, the latter species was included in the current review). Moreover, the documented leaf-mines of an unknown taxon (see Fig. 59 or in Stonis et al., 2016b: Figs. 27-32) were collected in the same area as all currently known adults (the type series) of S. imperatoria (Fig. 74); therefore the leaf-mine illustrated in Fig. 59 might belong to $S$. imperatoria.

Designation of the Stigmella circinata species group. This new group is the most similar and probably closely related to the boreal $S$. hemargyrella and S. sorbi groups; all these three groups (including the $S$. circinata group) share one very distinctive character (Fig. 75). It is interesting that in its male and female genitalia, the S. circinata group appears much more similar to the $S$. hemargyrella group than to $S$. sorbi group, whereas in its feeding habits (species biology), on the contrary, to the S. sorbi group. Unique diagnostic characters of $S$. circinata group (or at least the ones which distinguish the group from both most similar groups) are a highly specific, rounded juxta, and a phallus without manica. Currently the group comprises only one species known from the equatorial Andes, but more species are expected to be discovered in future.

\section{ACKNOWLEDGEMENTS}

We are indebted to O. Karsholt and the late Professor N. P. Kristensen (ZMUC) for the initial stimulus to start the Neotropical project together with generous support during its course as well as the loan of the Neotropical material. For helpful and frequent discussions on various host-plant plants (not only those which are listed in the current paper) we thank: Arvind Singh (Banaras Hindu University, Varanasi, India); Narayanan Nair Mohanan (Jawaharlal Nehru Tropical Botanic Garden and Research Institute, India); José Luis Fernández-Alonso (Universidad de Salamanca, Spain); Theodor C. H. Cole (Universität Heidelberg, Germany); Maximilian Weigend (University of Bonn, Germany); Franz Starlinger (Federal Research and Training Centre for Forests, Natural Hazards and Landscape, Vienna, Austria); Alexandre Monro (Royal Botanic Gardens Kew, London, UK).

This study was supported by the Research Foundation of the Lithuanian University of Educational Sciences (2016). Andrius Remeikis is grateful for the research stipend received in 2016 from the Research Foundation of the Research Council of Lithuania.

Received 13 October 2016

Accepted 14 November 2016

\section{References}

1. Diškus A, Stonis JR. Leaf-mining insects of Lithuania. The Nepticulidae (Lepidoptera): taxonomy, chorological composition and trophic relationships [monograph]. Kaunas: Lutute Publishers; 2012. 220 p. Lithuanian.

2. Johansson R, Nielsen ES, van Nieukerken EJ, Gustafsson B. The Nepticulidae and Opostegidae (Lepidoptera) of North West Europe. Fauna Entomol. Scand. 1990; 23(1/2): 1-739.

3. Puplesis R. The Nepticulidae of Eastern Europe and Asia: western, central and eastern parts. Leiden: Backhuys Publishers; 1994. $291 \mathrm{p}$. 
4. Puplesis R, Diškus A, Robinson GS. New Neotropical Nepticulidae (Lepidoptera) from the western Amazonian rainforest and the Andes of Ecuador. Bull Nat Hist Mus Entomol. 2002; 71(1): 19-58.

5. Puplesis R, Diškus A. The Nepticuloidea \& Tischerioidea (Lepidoptera) - a global review, with strategic regional revisions. Kaunas: Lututè Publishers; 2003. 512 p.

6. Puplesis R, Robinson GS. A review of the Central and South American Nepticulidae (Lepidoptera) with special reference to Belize. Bull Nat Hist Mus Entomol. 2000; 69(1): 3-114.

7. Remeikis R, Diškus A, Stonis JR. Preliminary trophic analysis of leaf-mining Nepticulidae: pronounced feeding strategies in Middle and South America? Biologija. 2016; 4: 207-214.

8. Scoble MJ. A revised cladistic classification of the Nepticulidae (Lepidoptera) with descriptions of new taxa mainly from South Africa. Transv Mus Monograph. 1983; 2: i-xi + 1-105.

9. Stevens PF. [Internet]. 2012. Angiosperm Phylogeny Website. Available from http://www. mobot.org/MOBOT/research/APweb/.

10. Stonis JR, Diškus A, Remeikis A, Gerulaitis V, Karsholt O. Leaf-mining Nepticulidae (Lepidoptera) from record high altitudes: documenting an entire new fauna in the Andean páramo and puna. Zootaxa. 2016a; 4181(1): $1-94$.

11. Stonis JR, Diškus A, Remeikis A, Karsholt O. Do leaf-mining Nepticulidae occur in the natural but so threatened Andean Polylepis forests? Biologija. 2016b; 62(2): 83-97.

12. Stonis JR, Diškus A, Remeikis A, Navickaite A. Study methods of Nepticulidae: micro-mounts of genitalia structures. In: Stonis JR, Hill SR, Diškus A, Auškalnis T, editors. Selected abstracts and papers of the First Baltic International Conference on Field Entomology and Faunistics. Vilnius: Edukologija Publishers; 2014. p. 32-35.
Jonas Rimantas Stonis, Arūnas Diškus, Andrius Remeikis, Nixon Cumbicus Torres

\section{PIETŲ AMERIKOS NEPTICULIDAE (LEPIDOPTERA), TROFIŠKAI SUSIJUSIŲ SU ROSACEAE, TYRIMAI ATSKLEIDE் TAKSO- NOMINĘ IR TROFINĘ RŪŠIŲ İAIROVĘ}

\section{Santrauka}

Straipsnyje pateikti naujausi Pietų Amerikos Rosaceae augalus minuojančių mažųjų gaubtagalvių (Nepticulidae) tyrimų rezultatai trumpai apžvelgiant ir apibendrinant anksčiau paskelbtus duomenis apie Nepticulidae, kurie mitybos ryšiais yra susiję su erškètinių augalų šeima. Aprašomos trys naujos mokslui rūšys: viena Hesperomeles obtusifolia (Pers.) Lindl lapų minuotoja (Stigmella circinata Diškus \& Stonis, sp. nov.) ir dvi Rubus spp. lapų minuotojos (S. rubiphagiella Diškus \& Stonis, sp. nov., ir Ectoedemia morae Diškus \& Stonis, sp. nov.); visos šios naujos rūšys buvo aptiktos Andų kalnuose, ties pusiauju. Taip pat straipsnyje pirmą kartą dokumentuotos Acaena L., Rubus L., Prunus L. ir Hesperomeles Lindl lapų minos, kurios priklauso iki šiol neaprašytiems Stigmella Schrank taksonams. Pirmą kartą aprašoma ir iki šiol nežinoma Stigmella nubimontana Puplesis \& Diškus patelè, skelbiamos S. nubimontana Puplesis \& Diškus ir S. rubeta Puplesis \& Diškus minų nuotraukos.

Nustatyta, kad aptiktos Rosaceae augalus minuojančių mažųjų gaubtagalvių rūšys tarpusavyje yra ganètinai skirtingos tiek morfologijos, tiek taksonomijos požiūriu. Remiantis suaugèlių genitalijų struktūrų ir lervų požymiais, Stigmella gentyje išskirta nauja $S$. circinata rūšių grupè, kuri palyginta su artimai giminiškomis Holarktyje paplitusiomis S. hemargyrella ir S. sorbi grupėmis.

Raktažodžiai: Ectoedemia Busck, lapų minos, mažieji gaubtagalviai, naujos rūšys, Nepticulidae, Pietų Amerika, Rosaceae, Stigmella Schrank 